\title{
Experimental Study of Destructive Distillation of Maiganga Coal: Analysis of Products' Yield and Composition
}

\author{
Habu Iyodo Mohammed ${ }^{1, *}$, Ali Lawan Yaumi ${ }^{1}$, Alhaji Shehu Grema ${ }^{1}$, Murtala Musa Ahmed ${ }^{1}$, \\ Abubakar Mohammed El-Jummah ${ }^{2}$ \\ ${ }^{1}$ Department of Chemical Engineering University of Maiduguri, Maiduguri, Nigeria \\ ${ }^{2}$ Department of Mechanical Engineering University of Maiduguri, Maiduguri, Nigeria
}

Email address:

mohammedhabu@unimaid.edu.ng (H. I. Mohammed)

${ }^{*}$ Corresponding author

To cite this article:

Habu Iyodo Mohammed, Ali Lawan Yaumi, Alhaji Shehu Grema, Murtala Musa Ahmed, Abubakar Mohammed El-Jummah. Experimental Study of Destructive Distillation of Maiganga Coal: Analysis of Products' Yield and Composition. American Journal of Chemical Engineering. Vol. 7, No. 6, 2019, pp. 135-140. doi: 10.11648/j.ajche.20190706.12

Received: January 26, 2020; Accepted: February 10, 2020; Published: February 14, 2020

\begin{abstract}
The research involves destructive distillation of Maiganga coal, analysis of the yields and characterization of condensable products. Maiganga coal was distillated in a pyrolyser, the condensable products were recovered in a three stage separator, and the products were collected over a range of temperatures. The yields' of the char was obtained by measuring the weight of the char and then divided by the starting weight of the coal sample. The condensable products yields were obtained in similar manner as the char. The yield of the gaseous product was obtained by subtracting the sum of yields of char and condensable products from unity. The yields of semi-coke, water and tar were 63,11 , and $7 \%$, respectively. The tar obtained was characterize using GC/MS to determine the chemical composition. The characterization was carried out using Agilent Gas Chromatography/ Mass Selective Detector (GC/MSD). The GC/MSD results show that the dominant compounds in the tar are aromatic, acid, and esters. However sulphur, nitrogen, chlorine, and fluorine compounds were present. The specific dominant compound is Benzeneacetic acid, 4-tetradecyl ester, $\left(\mathrm{C}_{22} \mathrm{H}_{36} \mathrm{O}_{2}\right)$ about $33 \%$, and the least were 1H-Thiopine, 2,3,6,7-tetrahydro-4,5-didehydro-3,3,6,6-tetramethyl $\left(\mathrm{C}_{10} \mathrm{H}_{16} \mathrm{OS}\right), \quad$ 1-oxide, 4-(2,5-Dihydro-3-methoxyphenyl)butylamine $\left(\mathrm{C}_{11} \mathrm{H}_{19} \mathrm{NO}\right)$ about $6 \%$. The coal may serve as feedstock for production of coke and aromatic compounds.
\end{abstract}

Keywords: Maiganga Coal, Yield, Agilent GC/MSD, Aromatic, Benzene Acetic Acid 4-Tetradecyl Ester

\section{Introduction}

Properties of Maiganga coal have been studied by many authors [1-3]. The potential of the coal for power generation and cement kiln firing has been previously reported by $[1,3]$. The yield and properties of gaseous and liquid products from destructive distillation of Maiganga coal has not been previously reported in literature. It is imperative to experimentally study the yields and properties of products to ascertain its potential for chemical manufacturing processes. Maiganga coal has been classified as sub-bituminous with volatile matters ranging from $29-50 \%$, with onset (ignition) temperature, and maximum devolatilzation temperature of 383 and $555^{\circ} \mathrm{C}$, respectively $[1,4]$. The significance of the data is that it tells possible volume of volatiles obtainable and range of temperature at which operation should be considered. It has been reported by [5] that average volatile matters in Maiganga coal is $32 \%$.

The products of the destructive distillation of coals are generally char, liquids and gases. The nature of the coal, conditions of the operation and geometry of the reactor dictates the proportions of the products and their chemical compositions $[6,7]$. It has been reported that temperature was the most sensitive variable [8] that affects coal distillation: very moderate temperatures resulting in evaporation only, medium temperatures gives rise to thermal degradation and very high temperatures leads to acetylene formation [9]. Destructive distillation of coal is of two broad categories, those which release small molecular side groups attached to the macromolecular network and those which break bonds holding the network together [10]. At moderate temperature 
above $300^{\circ} \mathrm{C}$, the constituents begins to breakdown, while macromolecular ring only decomposed at elevated temperature [11]. Reference [6] reported that the changes that occur in coal pyrolysis below temperature of $200^{\circ} \mathrm{C}$ does not involves covalent bonds, and the products are, water, volatile phenol and ammonia.

The yield of liquid and gases from coal distillation was reported to be more than the value of the volatile matters obtained from proximate analysis [12]. This development might be as a result of secondary reactions that occur in the reactor, which consumes some parts of solid that ought to remain char. Reference [12] studied the effect of temperature on yield of value added liquid and gaseous products form five coal of different source, the maximum point of liquid yield was found to be $700^{\circ} \mathrm{C}$. It has been reported by [13] that liquid yield could be improved with the aid of catalyst. The yield of light liquid components was reported to be improved in $\mathrm{CO}_{2}$ atmosphere [11]. The liquid products composition of low rank coal pyrolysis in hydrogen rich atmosphere was reported to be benzene, toluene, and xylene, while phenols oxygenated compounds are major products in inert environment [14].

Reference [15] studied pyrolysis of Hulun Bair lignite, it was found that the gas, tar, water and semi-coke yield were $17.56,8.64,21.34$ and 52.46 respectively. The composition of the tar was majorly phenols, cyclo alkane, aliphatics hydrocarbon, oxygenic compounds and heterocyclic compounds. Brown (2009) found that the compounds found in the liquid products include acetic acids, furans, levoglucosan, phenols, Guiaicols, syringols, aldehydes and ketones. Coal contains valuable industrial feedstock with economic value.

Environmental concern in utilization of coal as fuel has led to thinking on conversion of coal to less polluting fuel and chemical. Production of bulk and specialty chemicals, polymers and carbon materials from coals has gain popularity in recent decades. In China coal are the source of feedstock for aromatics, ammonia, methanol, and olefins [16]. The simulation of pyrolysis of Maiganga coal reveals that volatiles matter yields is maximum between 550 to $600^{\circ} \mathrm{C}$, and heating rate ranging between 50 to $100^{\circ} \mathrm{C} / \mathrm{min}$ [17]. The yield and properties of chemicals obtainable from Maiganga coal is yet to be ascertained. It is imperative to destructively distillate the coal, and conduct analyses on the products in order to reveal its potential application. The aim of the study is to characterize the liquid products from destructive distillation of Maiganga coal, and the objectives are to:

i. Collect and prepare Maiganga coal for pyrolysis;

ii. Pyrolyze the prepared coal;

iii. Collect and analyze the liquid products of the pyrolysis.

\section{Methodology}

\subsection{Sample Collection and Preparation}

A sample of Maiganaga coal was collected from Ashaka Cement factory in Gombe State. The ultimate and proximate analysis of Maiganga coal has been previously presented by [ 1 $18,19]$. It was crushed and sieved to obtain range of particle size. The lab scale destructive distillation plant reactor was cleaned, and the cooling water reservoir was filled. Before the pyrolysis experiments, coals were grounded and the finer particle fractions in a size range $0.075-0.15(\mathrm{~mm})$ were selected.

\subsection{Experimental Setup for Coal Distillation}

The distillation equipment comprises reactor, and three set of separators connected in series. The reactor is equipped electric heating device and temperature controller. The separators are equipped with water cooling system and digital pyrometer for monitoring the process temperatures. The closest, closer, and close separators to the furnace were designated as Separator \#1, 2, and 3 respectively. The photograph of the coal distillation equipment is presented in Figure 2.

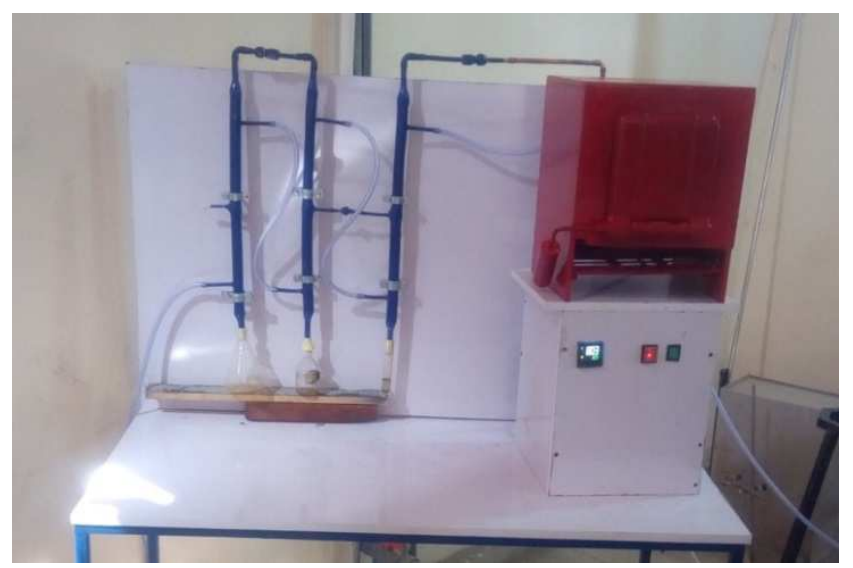

Figure 1. Destructive Distillation Unit for Coal Processing.

One hundred and twelve grams of Maiganga coal was fed into micro reactor and was tightly sealed, and the reactor was assembled into the furnace. The furnace exit pipe was connected to separators, which designed aid cooling. The condensed materials from the first separator was collected in the first collector, the uncondensed gases from the first collector is passed to the second separator, similarly the last one. The outlet of the last collector was channeled into distilled water to obtain soluble solution of soluble gases. The reactor temperature controller was set to $800^{\circ} \mathrm{C}$, and the furnace was switched on. The circulating cooling water is connected to chiller and the temperature was set at $20^{\circ} \mathrm{C}$, the system was switched on. The reactor temperature reaches the set temperature in 110 minutes, and was maintained for two hours. The three seperators were connected to a four way pyrometer to measure the temperature range at which the products were obtained. The volume and weight of samples of condensable components collected were measured and stored for physical and chemical properties analysis.

\subsection{Determination of Products Yield}

The char yields were obtained by weighing the char left in the reactor. The tar yields' were obtained by weighing the tar fractions. The gaseous product yield was calculated from the 
solid and liquid yield using equation (6), while the yields of other components were calculated using equation (2) to (5).

$$
\begin{aligned}
& Y_{i}=\frac{W_{i}}{W_{S}} x 100 \\
& Y_{\text {char }}=\frac{W_{\text {char }}}{W_{S}} \times 100 \\
& Y_{\text {Sep.1 water }}=\frac{W_{\text {water }}}{W_{S}} \times 100 \\
& Y_{\text {sep } .2 \text { tar }}=\frac{W_{\text {sep. } 2 \text { oil }}}{W_{S}} \times 100 \\
& Y_{\text {sep.3 tar }}=\frac{W_{\text {sep.3 oil }}}{W_{S}} \times 100 \\
& Y_{\text {gases }}=100-Y_{\text {char }}-Y_{\text {Sep.1 water }}-Y_{\text {sep.2 oil }}-Y_{\text {sep.3 oil }}
\end{aligned}
$$

Where $W_{\text {char }}, W_{\text {sep.1 water }}, W_{\text {sep.2 oil }}, W_{\text {sep.3 oil }}, W_{\text {sep.3 oil }}$ are the weight of various products recovered, and $Y_{i}$ are yields of the corresponding products.

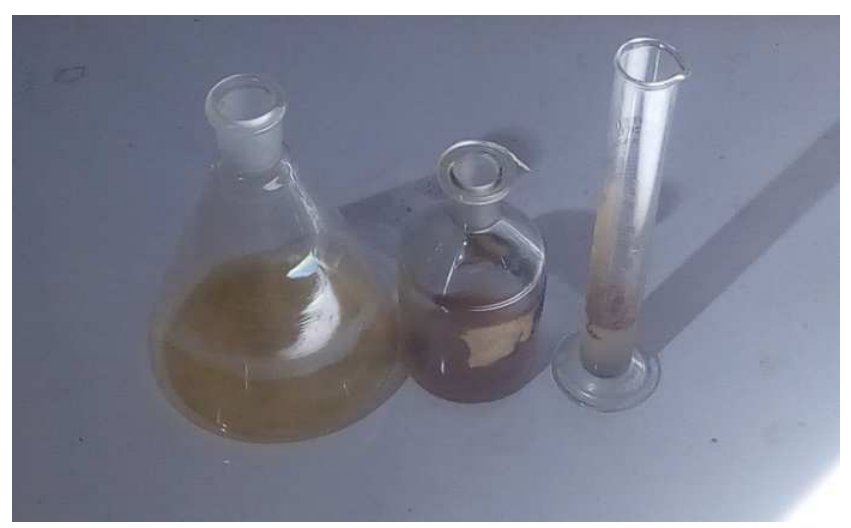

Figure 2. Samples of the Coal distillation Products.

\subsection{Determination of Chemical Composition}

The chemical compositions of the two samples were determined by subjecting the samples to Gas Chromatography mass spectrometer (GC-MS) analysis. GC/MS methods are used to help characterize the chemical composition of tar fractions. An Agilent 7890B GC and 5977A MSD were used. The GC portion of the instrument vaporizes the injected sample $(99.999 \%$ helium is used as a carrier gas at $1 \mathrm{~mL} / \mathrm{min})$ and separates compounds based on the column selection described. The compounds are then analyzed and detected in the MS portion of the instrument using the electron ionization mode. Ideally, specific compounds are detected which produce specific signals at a corresponding retention times. An $\mathrm{m} / \mathrm{z}$ range from 30 to 340 is scanned, and standard mass spectra with $70-\mathrm{eV}$ ionization energy is recorded. The Varian GC/MS software package includes a NIST library that is used to match the resulting mass spectra peak for identification if necessary. The injector temperature on the instrument is maintained at $250^{\circ} \mathrm{C}$, and the $\mathrm{GC} / \mathrm{MS}$ interface is maintained at $235^{\circ} \mathrm{C}$. The initial oven heating begins at $45^{\circ} \mathrm{C}$ for four minutes and is brought to the GC/MS interface temperature at a heating rate of $5^{\circ} \mathrm{C} / \mathrm{min}$. The GC/MS interface temperature is then maintained for some time. Tar samples on the order of
$0.25 \mathrm{~g}$ are diluted in HPLC grade hexane at $4.5 \%$-wt (95.5\%-wt. hexane). The bio-oil is homogenized with the hexane by mixing with a vortex mixer, and then filtered with a $0.2 \mu \mathrm{m}$ filter before placing into a GC/MS sample vial. The compositions of the chemical species detected were computed from the area of the peaks of the spectrum.

\section{Results and Discussion}

\subsection{Process Equipment Temperature History}

The temperature history of the process is presented in Figure 2. The set temperature was attained in 120 minutes. The temperature was able to maintain the reactor temperature close to the set point with little fluctuation in magnitude of $8^{\circ} \mathrm{C}$. Separator $\# 1,2$, and 3 maximum temperatures were 195 , 139 and $98^{\circ} \mathrm{C}$, respectively. At the set temperature of the furnace, separator \#1 temperature range is in magnitude of $19^{\circ} \mathrm{C}$, that of $\# 2$ is $11^{\circ} \mathrm{C}$, while separator three fluctuates in between 98 to $69^{\circ} \mathrm{C}$.

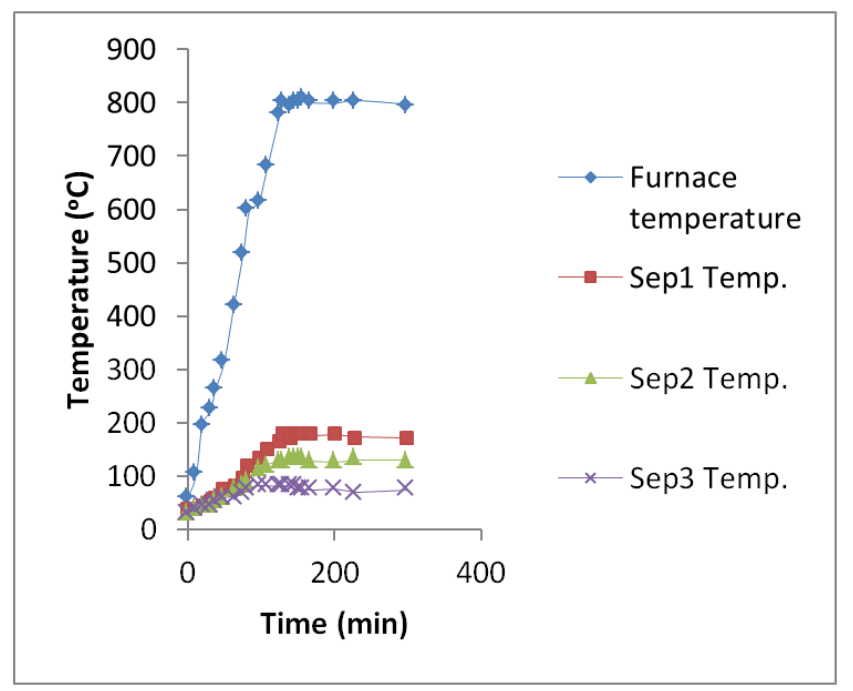

Figure 3. Temperature Profile of the Coal Distillation Units.

\subsection{Products Yield Analysis}

The products of coal distillation include char, oily substance, water, and gases. The product distribution allowed the spectrum of pyrolysis to be examined. The major products obtained from separator 1 were water with floating particles, which was $7.4 \%$ of the coal sample. Products from separators 2 and 3 are oily. The separator 2 product is brownish while that of separator 3 is pale yellow in colour. The percentage of mass recovered from separator 2 and 3 were 6.9 and 5.7 grammes, respectively. The char (semi-coke) was weighed to be 71 grammes. The percentage of products yield computed is presented in Table 1.

Table 1. Percentage of products yields.

\begin{tabular}{llll}
\hline Sources & Products & Mass recovered (g) & Yield (\%) \\
\hline Separator \#1 & Water & 8.3 & 7.4110 \\
Separator \#2 & Tar & 6.9 & 6.1607 \\
Separator \#3 & tar & 5.7 & 5.0892 \\
\hline
\end{tabular}




\begin{tabular}{llll}
\hline Sources & Products & Mass recovered $(\mathbf{g})$ & Yield (\%) \\
\hline Reactor & Semi-coke & 71 & 63.3928 \\
Separator \#3 & gases & & 19.7321 \\
\hline
\end{tabular}

The products distributions obtained may not be accurate due sticking of some liquid products on the wall of the separator, this may affects the accuracy of the entire products distribution. This results conform to the work of [15] on Hulun Bair coal. They obtained semi-coke, gases, and water as $52 \%$, $17 \%$, and $7 \%$ respectively, while in this study the semi-coke, gases and water recovered were about $63 \%, 19 \%$ and $7 \%$ respectively. These little discrepancies might be due to differences in maturity of the coal and condition of operation.
Maiganaga coal might be more mature than Hulun Bair lignite. The high yield of semi-coke in this study signifies that Maiganga coal has potential for development into chemicals and coke for steel industry and is agreement with the findings of [5] that average volatile matter in Maiganga coal is $32 \%$, in this study the volatiles is about $37 \%$.

\subsection{Chemical Composition of Maiganga Coal Distillates}

The spectrum of the GC/MSD analysis of tar obtained on destructive distillation of Maiganaga coal is presented in Figure.

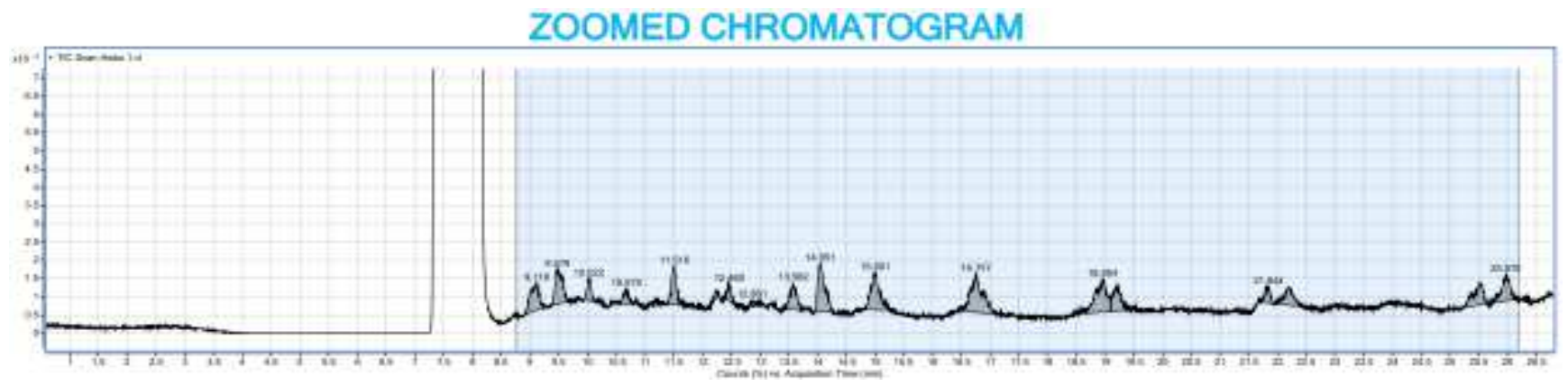

Figure 4. Spectrum of the GC/MSD analysis of Maiganga Coal Tar.

The chemical compounds detected include alkene, aromatics, oxygenic, halogen, nitrogenous, sulphur compounds and heterocyclic. These compounds and their chemical formula are presented in Table 2.

Table 2. Chemical compound detected in the Tar of Maiganga Coal.

\begin{tabular}{|c|c|}
\hline Chemical Compound & Chemical Formula \\
\hline 2-Naphthol, 1,2,3,4,4a,5,6,7-octahydro-4a-methyl- & $\mathrm{C}_{11} \mathrm{H}_{18} \mathrm{O}$ \\
\hline 3-Caren-10-al & $\mathrm{C}_{10} \mathrm{H}_{14} \mathrm{O}$ \\
\hline 4-(2,5-Dihydro-3-methoxyphenyl)butylamine & $\mathrm{C}_{11} \mathrm{H}_{19} \mathrm{NO}$ \\
\hline 1H-Thiopine, 2,3,6,7-tetrahydro-4,5-didehydro-3,3,6,6-tetramethyl-, 1-oxide & $\mathrm{C}_{10} \mathrm{H}_{16} \mathrm{OS}$ \\
\hline trans-Z- $\alpha$-Bisabolene epoxide & $\mathrm{C}_{15} \mathrm{H}_{24} \mathrm{O}$ \\
\hline 2,5-Octadecadiynoic acid, methyl ester & $\mathrm{C}_{19} \mathrm{H}_{30} \mathrm{O}_{2}$ \\
\hline 5-Benzofuranacetic acid, 6-ethenyl-2,4,5,6,7,7a-hexahydro-7a-hydroxy-3,6-dimethyl- $\alpha$-methylene-2-oxo-, methyl ester & $\mathrm{C}_{15} \mathrm{H}_{20} \mathrm{O}_{5}$ \\
\hline Oct-3-ene-1,5-diyne, 3-t-butyl-7,7-dimethyl- & $\mathrm{C}_{14} \mathrm{H}_{20}$ \\
\hline 5,8,11-Heptadecatriynoic acid, methyl ester & $\mathrm{C}_{18} \mathrm{H}_{24} \mathrm{O}_{2}$ \\
\hline trans-calamenene & $\mathrm{C}_{15} \mathrm{H}_{22}$ \\
\hline Bicyclo[4.1.0]heptan-2-ol, 1-phenyl-, endo- & $\mathrm{C}_{13} \mathrm{H}_{16} \mathrm{O}$ \\
\hline Falcarinol & $\mathrm{C}_{17} \mathrm{H}_{24} \mathrm{O}$ \\
\hline Azulene, 1,4-dimethyl-7-(1-methylethyl)- & $\mathrm{C}_{15} \mathrm{H}_{18}$ \\
\hline Benzeneacetic acid, 4-tetradecyl ester & $\mathrm{C}_{22} \mathrm{H}_{36} \mathrm{O}_{2}$ \\
\hline Benzene, 1,1'-[3-(3-cyclopentylpropyl)-1,5-pentanediyl]bis- & $\mathrm{C}_{25} \mathrm{H}_{34}$ \\
\hline Z,Z,Z-1,4,6,9-Nonadecatetraene & $\mathrm{C}_{19} \mathrm{H}_{32}$ \\
\hline 1-Octadecanesulphonyl chloride & $\mathrm{C}_{18} \mathrm{H}_{37} \mathrm{ClO}_{2} \mathrm{~S}$ \\
\hline Benzene, 1,1'-[3-(3-cyclopentylpropyl)-1,5-pentanediyl]bis- & $\mathrm{C}_{25} \mathrm{H}_{34}$ \\
\hline 3-Trifluoroacetoxypentadecane & $\mathrm{C}_{17} \mathrm{H}_{31} \mathrm{~F}_{3} \mathrm{O}_{2}$ \\
\hline 3-Trifluoroacetoxypentadecane & $\mathrm{C}_{17} \mathrm{H}_{31} \mathrm{~F}_{3} \mathrm{O}_{2}$ \\
\hline
\end{tabular}

The chemical composition of tar obtained from separator \#2 and \#3 is presented in Figure 3. The product composition is dominated by Benzeneacetic acid, 4-tetradecyl ester $\left(\mathrm{C}_{22} \mathrm{H}_{36} \mathrm{O}_{2}\right)$ about $33 \%$, other compounds are bisabolene epoxide, falcarinol, and furan. As shown in Figure 3, all the compounds contain oxygen atom with exception of trans azulene $\left(\mathrm{C}_{15} \mathrm{H}_{18}\right), \quad$ calamenene $\left(\mathrm{C}_{15} \mathrm{H}_{22}\right)$, Z,Z,Z-1,4,6,9-Nonadecatetraene $\left(\mathrm{C}_{19} \mathrm{H}_{32}\right)$. However, nitrogen compound such 4-(2,5-Dihydro-3-methoxyphenyl)butylamine sulphur compounds such as $\left(\mathrm{C}_{11} \mathrm{H}_{19} \mathrm{NO}\right)$, 2,3,6,7-tetrahydro-4,5-didehydro-3,3,6,6-tetramethyl-, 1-oxide $\left(\mathrm{C}_{10} \mathrm{H}_{16} \mathrm{OS}\right), \quad$ and 1-Octadecanesulphonyl chloride, $\left(\mathrm{C}_{18} \mathrm{H}_{37} \mathrm{ClO}_{2} \mathrm{~S}\right)$, halogen compound such as 3-Trifluoroacetoxypentadecane $\left(\mathrm{C}_{17} \mathrm{H}_{31} \mathrm{~F}_{3} \mathrm{O}_{2}\right) \quad$ and $\mathrm{C}_{18} \mathrm{H}_{37} \mathrm{ClO}_{2} \mathrm{~S}$ were present in the sample. 


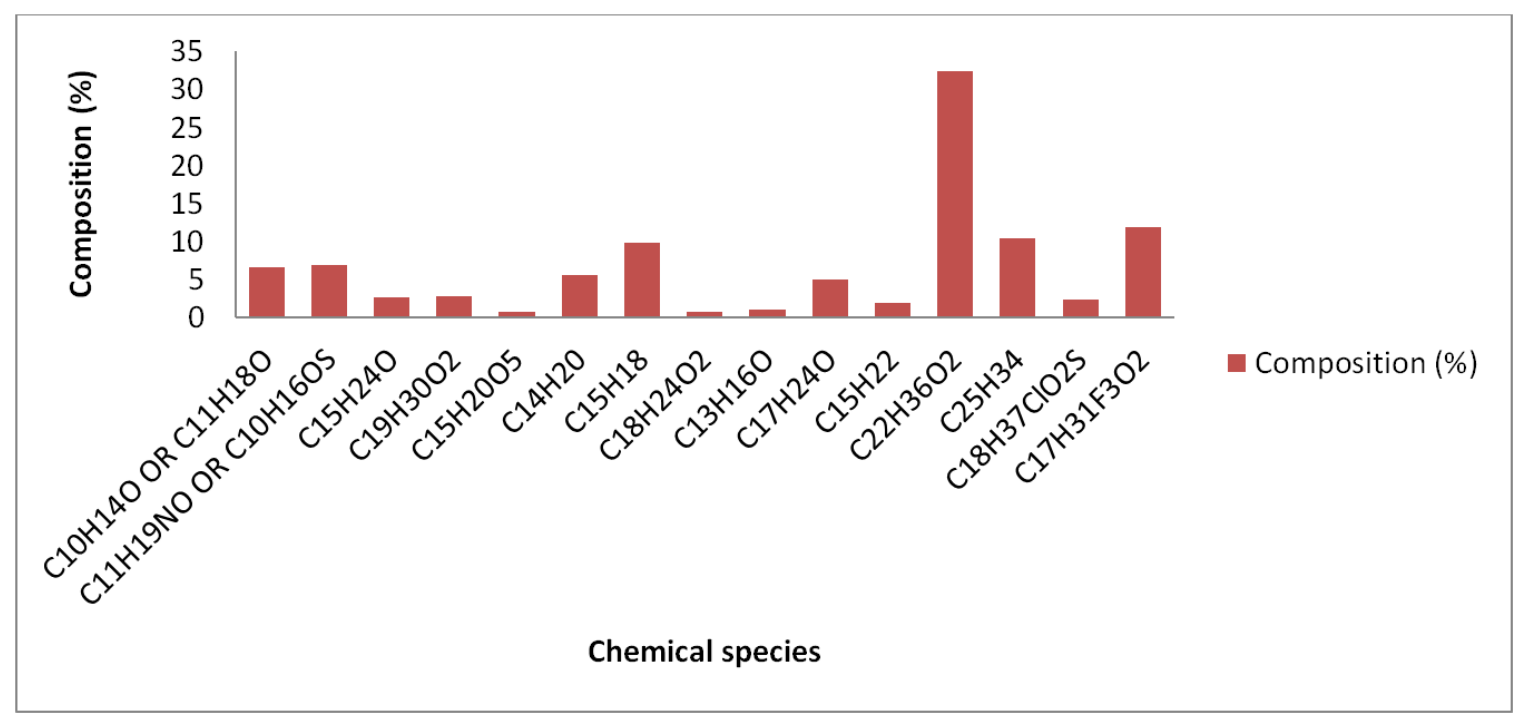

Figure 5. Chemical Composition of Products from Separator \#2 Quantified by GC/MSD.

The polycyclic molecules obtained might be due to cracking of the coal macromolecule and condensation reaction of the smaller molecules that occurs in the reactor. Nie, Fan, Meng, Tao, Zhang (2017) reported that condensation reactions do occur at temperature above $700^{\circ} \mathrm{C}$.

\section{Conclusion}

The experimental results from destructive distillation of Maiganaga coal at $800^{\circ} \mathrm{C}$, is summarized as follows:

i. the operation of the equipment at $800^{\circ} \mathrm{C}$ gives fractions of products, which include water, tars and semi-coke. The products obtained during the pyrolysis experiments show that low temperature pyrolysis process can obtain high yield of gas and tar. The gas product was quantified to be $14 \%$. The water yield may be attributed to the moisture content and decomposition of hydroxyl groups in the coal. The high yield of semi-coke at higher temperature of $800^{\circ} \mathrm{C}$ indicates relative maturity of the coal and may be good blending stuff for metallurgical coke production.

ii. The high composition of aromatics and esters in the distillates indicates that products from Maiganga coal can serve as raw materials in petrochemical industries. This study has revealed that Maiganga coal contain reasonable amount of chlorine and fluorine, which has not been presented in previous studies. The presence of amine, sulphonyl, and thiopene in the distillate indicates that substantial amount of nitrogen and suphur content of the coal are being reduced from the semi-coke on pyrolysis.

\section{Acknowledgements}

The authors acknowledge the sponsorship of Nigeria Tertiary Education Trust Fund (TETFund) Under Institution Base Research (IBR) Programme.

\section{References}

[1] A. Nyakuma, Bemgba B., Jauro A., "Physicochemical Characterization and Thermal Decomposition of Maiganga Coal,” De Gruyter, vol. LXII, no. 3, pp. 6-11, 2016.

[2] A. Babagana, U. Abdullahi, J. M. El-nafaty, and M. Gado, "Quality Assessment of Coal Deposits around Molko Area," $J$. Appl. Geol. Geophys., vol. 5, no. 3, pp. 101-110, 2017.

[3] L. J. Mudashiru, "Suitability Assessment of Kurumu, Garin-maiganga, Gindi- akwati and Ogboyoba Coal Deposit Properties for Power Generation Suitability Assessment of Kurumu, Garin-maiganga, Gindi- akwati and Ogboyoba Coal Deposit Properties for Power Generation,” 2016.

[4] M. Chukwu, C. O. Folayan, G. Y. Pam, and D. O. Obada, "Characterization of Some Nigerian Coals for Power Generation," J. Combust., vol. 2016, no. 9728278, pp. 1-11, 2016.

[5] U. S. Onoduku, "Chemistry of Maiganga Coal Deposit, Upper Benue," vol. 2, no. 3, pp. 80-84, 2014.

[6] Q. Nie, Fan, Meng, Tao, Zhang, "Pyrolysis of Low-Rank Coal: From Research to Practice," in Pyrolysis, 2017, pp. 319-339.

[7] B. Yang and L. Wang, "Review of advance on coal pyrolysis mechanism," J. Chem. Pharm. Res., vol. 6, no. 3, pp. 421-423, 2014.

[8] H. S. V. Kramer, Robert A, Liberty Pelter, "Enhancing Coke Production Energy Efficiency While Reducing Emissions," in AISTech 2011 Conference Proceedings, 2011, pp. 1-12.

[9] A. Raðenoviæ, "Pyrolysis of Coal," Piroliza ugljena, Kem. Ind, vol. 55 , no. 7-8, pp. 311-319, 2006.

[10] P. R. Solomon and M. A. Serio, "Progress in Coal Pyrolysis Research," 1993.

[11] Y. D. Y. and S. V. P. Vijayaragavan, Krishnamoorthy, "Influence of Pyrolysis Gas on Volatile Yield and $\mathrm{CO}_{2}$ Reaction Kinetics of the Char Samples Generated in," Energies, 2018. 
[12] T. Takafumi, Kawamura, Shigeru, Hashimoto, Mitsuhiro, Sakawa, Hiyoruku, Kozuru, Hiroshi, Lida, "Study on Coal Flash Pyrolysis," 1993.

[13] M. N. Amin, Y. Li, and X. Lu, "In Situ Catalytic Pyrolysis of Low-Rank Coal for the Conversion of Heavy Oils into Light Oils," Adv. Mater. Sci. Eng., vol. 2017, no. 561252, pp. 1-8, 2017.

[14] J. N. Brown, "Development of a lab-scale auger reactor for biomass fast pyrolysis and process optimization using response surface methodology by," Iowa State University, 2009.

[15] Z. Ying, Xu, Guoji, Zhang, Lei, Chen, Xiaokuo, Ding and Yongfa, "Pyrolysis Products Properties from Lignite," Asian J. Chem., vol. 25, no. 9, pp. 4828-4832, 2013.
[16] N. Herminé, Non-fuel uses of coal. London, 2014.

[17] A. L. Yaumi, H. I. Mohammed, A. S. Grema, A. M. El-jummah, and M. M. Ahmed, "Simulation of Flash Pyrolysis of Maiganga Coal Using Modified Straight First Order Reaction Model," Res. J. Chem. Eng. Process., vol. 1, no. 1, pp. 2-7, 2019.

[18] S. A. Ryemshak, A. Jauro, J. D. Putshaka, and R. M. Sori, "Ultimate Analysis of some Nigerian coal: Ranking and Suitable Application," Int. J. Eng. Appl. Sci., vol. 3, no. 10, pp. 31-35, 2016.

[19] B. B. Nyakuma, "Oxidative Thermal Analysis of Nigerian Coals," J. Ener. Env., 4 (1), 2-5, 2012. 